\title{
Successful management of Aspergillus scleritis by medical and surgical treatment
}

\begin{abstract}
Background Inflammatory scleral disease is frequently associated with autoimmune disorders and only occasionally caused directly by an infective agent. Fungal infections primarily involving the sclera are rare, and the outcome is generally poor. Here we report three patients with post-operative Aspergillus scleritis who were successfully managed by medical therapy and surgical intervention.
\end{abstract}

Patients Scleral infection with Aspergillus sp. was diagnosed 6 and 5 months after cataract extraction in a 76-year-old diabetic and an 82-year-old woman respectively, and in a 54-year-old man 3 months after trabeculectomy. Swabs and/or scrapings had not been conclusive and the diagnosis of Aspergillus infection was established in all cases only after scleral biopsy.

Results The infection was eliminated in all cases. This was achieved in one eye by treatment with oral itraconazole in combination with systemic and topical amphotericin $B$. The two patients with fungal scleritis after cataract extraction required in addition to the medical therapy (oral itraconazole, topical econazole and amphotericin B) scleral excisions and patch grafts to control infection.

Conclusion Fungal scleritis may remain undiagnosed for months. A scleral biopsy may be necessary to establish this diagnosis. Prolonged systemic antifungal therapy alone may not eradicate fungal infection. Surgical excision improves the outcome of fungal scleritis.

Key words Amphotericin B, Antifungal, Econazole, Fungus, Imidazole, Itraconazole, Scleritis, Triazole

Inflammatory scleral disease is frequently associated with autoimmune disorders and is only occasionally caused directly by an infective agent. ${ }^{1}$ Fungal infections primarily involving the sclera are extremely rare, but have been reported after trauma, ${ }^{2}$ retinal detachment
WOLFGANG BERNAUER,

BRUCE D.5. ALLAN,

JOHN K.G. DART

surgery, ${ }^{3,4}$ treatment of pterygium, ${ }^{5,6}$ cataract surgery, 7,8 and in association with systemic fungal infection. ${ }^{911)}$ The outcome is generally poor (Table 1). Here we report three patients with post-operative Aspergillus scleritis who were successfully managed by medical therapy and surgical interventions.

\section{Case reports}

Case 1

This 76-year-old diabetic woman underwent uncomplicated extracapsular cataract extraction and posterior chamber intraocular lens insertion via a corneoscleral section in her left eye. She received post-operative treatment with topical steroids and antibiotics. Uncorrected vision in this eye was $6 / 60$, thought to be due to agerelated maculopathy. One month postoperatively 'anterior uveitis' was noticed that settled with topical steroids. Three weeks later, in January 1994, the eye became painful with loss of vision down to correct light projection. An infiltrate at one of the stitches and a small hypopyon were recorded. These signs resolved on topical gentamicin and ceftazidime. Two months later, in March 1994, some of the sutures were removed and gentamicin $15 \mathrm{mg} / \mathrm{ml}$ and ceftazidime $50 \mathrm{mg} / \mathrm{ml}$ continued, since conjunctival hyperaemia was still present. Three weeks later a stitch abscess around one of the remaining loose sutures was diagnosed and swabs taken from this area and from beneath the adjacent conjunctiva. There was growth of Aspergillus on only one of several swabs.

Contamination was suspected and the area reswabbed without any microbial growth. The antibiotics were discontinued and topical econazole instituted. After two further weeks without signs of improvement the patient was referred to Moorfields Eye Hospital.

Vision was 'counting fingers' at $1 \mathrm{~m}$. Abnormal findings on ocular examination were limited to the anterior segment of the left eye. The conjunctiva was hyperaemic and the sclera at the upper part of the globe thickened. Therapy with topical and systemic ciprofloxacin was started and the econazole drops continued, but the scleritis persisted. A scleral biopsy was
W. Bernauer

University of Zurich Department of

Ophthalmology

Frauenklinikstrasse 24

$\mathrm{CH}-8091$ Zurich

Switzerland

Fax: +4112554438

W Bernauer

B.D.S. Allan

J.K.G. Dart

Moorfields Eye Hospital and Institute of Ophthalmology London UK

W.B. was supported in part by the Swiss National Science Foundation and by a locally organised research scheme from Moorfields Eye Hospital

Proprietary interest: None 
Table 1. Published reports on fungal scleritis

\begin{tabular}{|c|c|c|c|c|c|}
\hline $\begin{array}{l}\text { Author(s) and } \\
\text { reference }\end{array}$ & $\begin{array}{l}\text { Predisposing } \\
\text { condition }\end{array}$ & Fungal isolate & $\begin{array}{l}\text { Medical antifungal } \\
\text { therapy }\end{array}$ & Surgical therapy & $\begin{array}{l}\text { Outcome (visual } \\
\text { acuity) }\end{array}$ \\
\hline Köllner, $^{2} 1906$ & $\begin{array}{l}\text { Trauma, piece of } \\
\text { wood as foreign } \\
\text { body }\end{array}$ & $\begin{array}{l}\text { Aspergillus or } \\
\text { Trichophyton }\end{array}$ & & & 'Healed' \\
\hline Chaillous, ${ }^{9} 1912$ & $\begin{array}{l}\text { Systemic } \\
\text { sporotrichosis }\end{array}$ & Sporotrichum & $\begin{array}{l}\text { Oral potassium } \\
\text { iodide }\end{array}$ & & 'Much improved' \\
\hline $\begin{array}{l}\text { Podedworny and } \\
\text { Suie, }{ }^{7} 1964\end{array}$ & Cataract extraction & Paecilomyces sp. & $\begin{array}{l}\text { IV and topical } \\
\text { amphotericin B }\end{array}$ & Excision & 'Completely healed' \\
\hline Lincoff et al., ${ }^{3} 1965$ & $\begin{array}{l}\text { Diabetes mellitus; } \\
\text { scleral buckling } \\
\text { operation }\end{array}$ & Probably M. mycosis & IV amphotericin B & Implant removal & 'Eye lost' \\
\hline $\begin{array}{l}\text { Milauskas et al., } \\
1967\end{array}$ & $\begin{array}{l}\text { Diabetes mellitus; } \\
\text { scleral buckling } \\
\text { operation }\end{array}$ & $\begin{array}{l}\text { 'Yeast cells'; exact } \\
\text { identification on } \\
\text { morphological basis } \\
\text { not possible }\end{array}$ & & & Enucleation \\
\hline Stenson et al., ${ }^{10} 1982$ & $\begin{array}{l}\text { IV drug use; } \\
\text { systemic Aspergillus } \\
\text { disease } 5 \text { years } \\
\text { previously }\end{array}$ & Aspergillus oryzae & $\begin{array}{l}\text { Topical natamycin } \\
\text { and amphotericin B, } \\
\text { oral flucytosine, IV } \\
\text { amphotericin B }\end{array}$ & Biopsies & $\begin{array}{l}\text { 'Complete } \\
\text { resolution' }\end{array}$ \\
\hline Margo et al., 1988 & $\begin{array}{l}\text { Pterygium excision/ } \\
\text { irradiation }\end{array}$ & Aspergillus sp. & $\begin{array}{l}\text { Topical natamycin, } \\
\text { topical miconazole, } \\
\text { oral flucytosine }\end{array}$ & None & Enucleation \\
\hline $\begin{array}{l}\text { Reynolds and } \\
\text { Alfonso, }{ }^{20} 1991\end{array}$ & Not reported & Acremonium & Topical natamycin & Not reported & Not reported \\
\hline Carlson et al., ${ }^{8} 1992$ & Cataract surgery & Aspergillus flavus & $\begin{array}{l}\text { Topical } \\
\text { amphotericin B, oral } \\
\text { ketoconazole and } \\
\text { itraconazole }\end{array}$ & Biopsies & $6 / 6$ \\
\hline \multirow[t]{4}{*}{ Moriarty et al., ${ }^{6} 1993$} & $\begin{array}{l}\text { Pterygium excision/ } \\
\text { irradiation }\end{array}$ & Petriellidium boydii & $\begin{array}{l}\text { Topical natamycin, } \\
\text { oral ketoconazole, IV } \\
\text { amphotericin B }\end{array}$ & $\begin{array}{l}\text { Debridement, } \\
\text { lamellar and } \\
\text { penetrating grafts }\end{array}$ & $6 / 36$ \\
\hline & $\begin{array}{l}\text { Pterygium excision/ } \\
\text { irradiation }\end{array}$ & Petriellidium boydii & $\begin{array}{l}\text { Topical natamycin, } \\
\text { IV amphotericin B }\end{array}$ & Lamellar grafts & Enucleation \\
\hline & $\begin{array}{l}\text { Pterygium excision/ } \\
\text { irradiation }\end{array}$ & Scedosporium inflatum & $\begin{array}{l}\text { Topical natamycin, } \\
\text { oral fluconazole, IV } \\
\text { amphotericin B }\end{array}$ & $\begin{array}{l}\text { Debridement, } \\
\text { lamellar grafts }\end{array}$ & $6 / 24$ \\
\hline & $\begin{array}{l}\text { Pterygium excision / } \\
\text { irradiation }\end{array}$ & Fusarium & $\begin{array}{l}\text { Topical natamycin, } \\
\text { oral ketoconazole }\end{array}$ & Debridement $(2 \times)$ & $6 / 6$ \\
\hline
\end{tabular}

IV, intravenous.

taken that contained fungal elements consistent with Aspergillus sp. (Fig. 1). Oral itraconazole, $200 \mathrm{mg}$ per day, was instituted and repeated injections of subconjunctival amphotericin B given. The scleral inflammation deteriorated slowly over the next 6 weeks and a necrotic area, measuring $3 \times 4 \mathrm{~mm}$, developed (Fig. 2). At this stage therapeutic surgery was planned.

An excision of the affected sclera and a deep lamellar dissection of the adjacent cornea was carried out (Fig. 3). The defect was covered with one corneal patch graft (Fig. 4) and antifungal therapy was continued as before. Over the next 4 weeks there was further expansion of the scleritis (Fig. 5). The patch graft was therefore removed. The necrotic borders were debrided and two donor corneas were required to fill the resulting large fullthickness defect. Systemic treatment with itraconazole was stopped since the patient had, on the third day after the intervention, developed a cerebral transient ischaemic attack. On 1 August 1994 the topical antifungal treatment was stopped. The eye remained quiet and the sutures were removed in December 1994 (Fig. 6). Astigmatism remained +12 in 170 and corrected vision $(+5 /-12 \times 80)$ was $6 / 18$.

\section{Case 2}

This otherwise healthy 82-year-old woman underwent uncomplicated extracapsular cataract extraction and posterior chamber intraocular lens insertion via a corneoscleral section in her left eye. She received standard post-operative treatment with topical steroids and antibiotics. At 4 weeks corrected visual acuity was $6 / 9$ and the post-operative appearance was normal. Six weeks post-operatively she noticed ocular discomfort and the eye became progressively more painful with loss of vision down to correct light perception. A stitch abscess around the most nasal suture was diagnosed and swabs taken from this area. Topical treatment with methicillin and gentamicin forte was started. Oral flucloxacillin $500 \mathrm{mg}$ and amoxicillin $500 \mathrm{mg}$ were given at the same time four times a day and twice per day respectively. The culture showed growth of Staphylococcus epidermidis and the antibiotic treatment was subsequently changed to fucidic acid drops and oral fucidin $100 \mathrm{mg}$ three times daily, later increased to $1 \mathrm{~g}$ per day. The subconjunctival abscess was drained and, as there was no improvement and signs of intraocular 


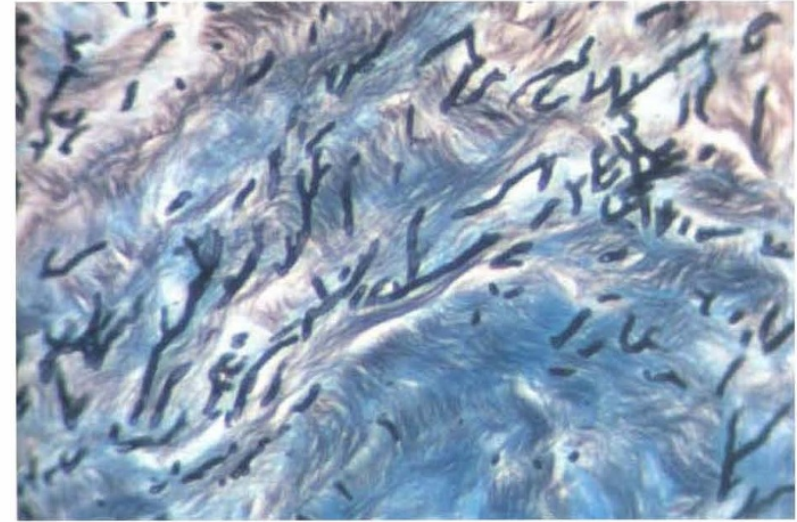

Fig. 1. Septate fungal hyphae with dichotomous branching in the scleral biopsy specimen of case 1. Hyphae appear black against a green background when the specimen is stained with Grocott-Gomori methamine silver $(x 400)$.

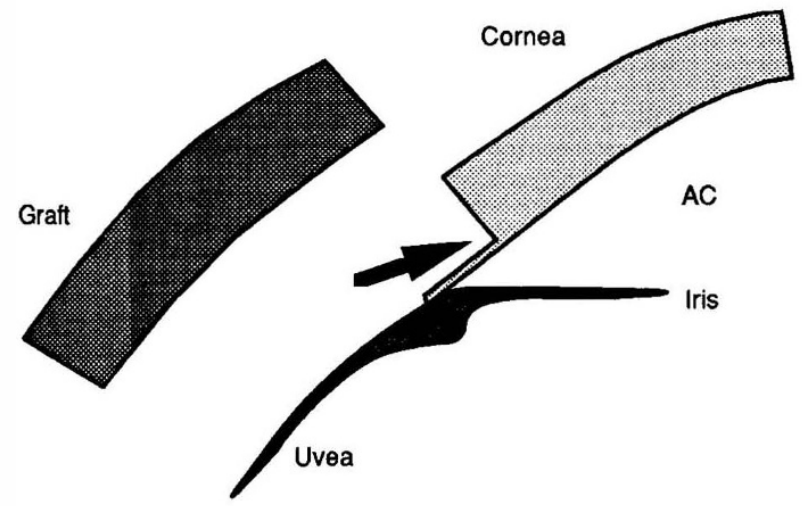

Fig. 3. Case 1. Schematic drawing of the technique that was used to excise the necrotic tissue. Deep lamellar dissection (arrow) followed macroscopic clearance of the infected tissue at the limbus without entering the anterior chamber.

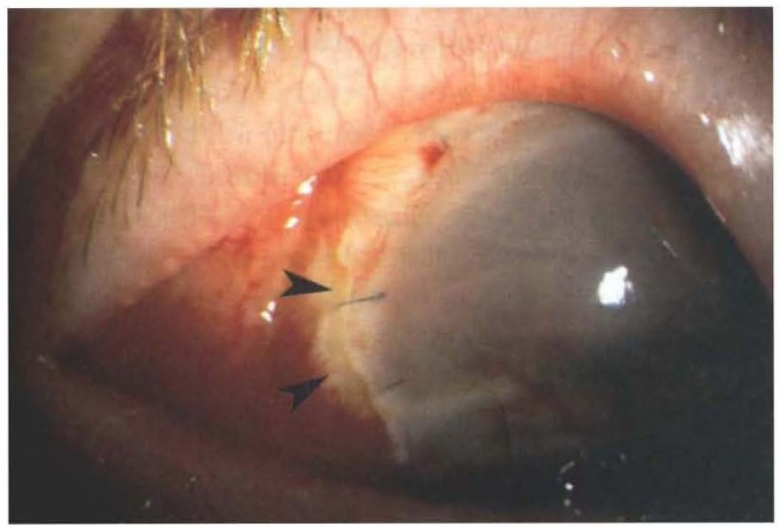

Fig. 5. Case 1. Over the next 4 weeks there was further expansion of the scleritis. The graft was subsequently removed to allow debridement of the necrotic borders. Two large grafts were then sutured in to cover the defect.

inflammation developed, an aqueous tap taken.

Although no bacterial growth developed in the cultured aqueous, Staphylococcus endophthalmitis was suspected. On 14 January 1994, i.e. 1 week after the initial diagnosis of a 'suture abscess', the patient was referred to Moorfields Eye Hospital.

Visual acuity was 6/60 and on examination a hyperaemic and thickened conjunctiva was found. The corneal wound was slightly infiltrated with some sutures

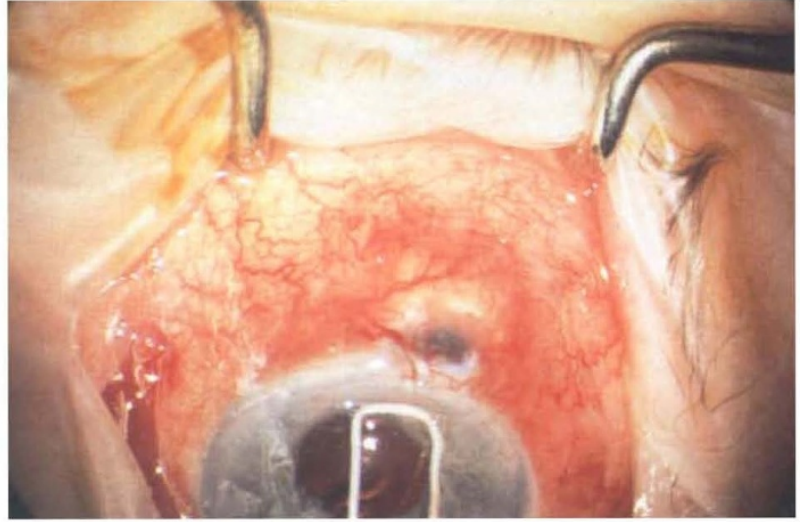

Fig. 2. Case 1. The left eye 7 months after uneventful cataract extraction. The scleritis had deteriorated slowly over the preceding weeks despite systemic and topical antifungal treatment. A necrotic area is now visible and excision of the affected sclera is planned.

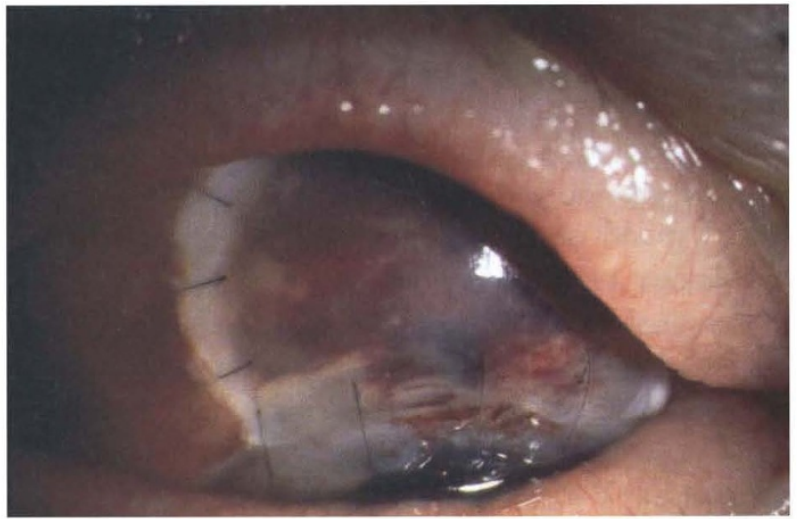

Fig. 4. Case 1. The debridement resulted in a large sclero-corneal defect that was covered with a large corneal patch graft.

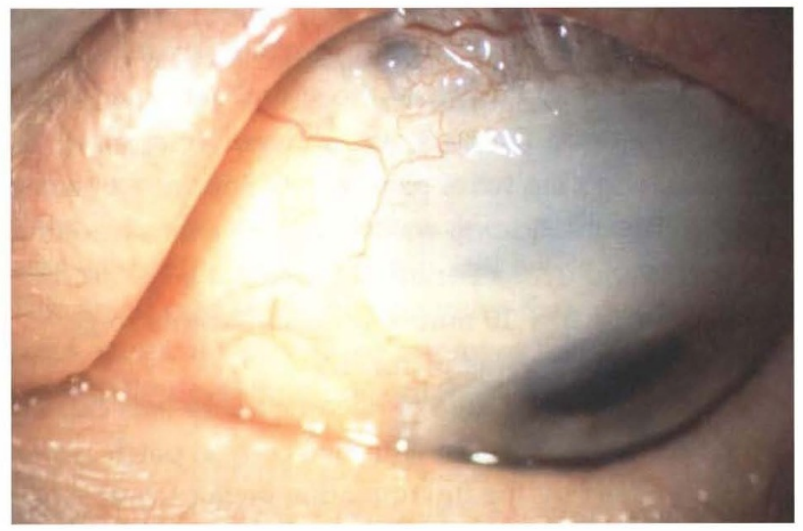

Fig. 6. Case 1. The same eye 5 months later. The antifungal treatment had been stopped 4 months previously. Visual acuity is now 6/18.

still in situ. There was a moderate to severe inflammation in the anterior chamber with cells and flare, but no hypopyon. Fundoscopy was difficult, but signs of a severe vitritis were absent. Aqueous and vitreous taps were taken, but no micro-organisms were grown. Intravitreal injections of amikacin $0.4 \mathrm{mg}$ and vancomycin $1.0 \mathrm{mg}$ were given and intravenous ciprofloxacin $200 \mathrm{mg}$ twice a day together with oral steroids started. The topical treatment was changed to 


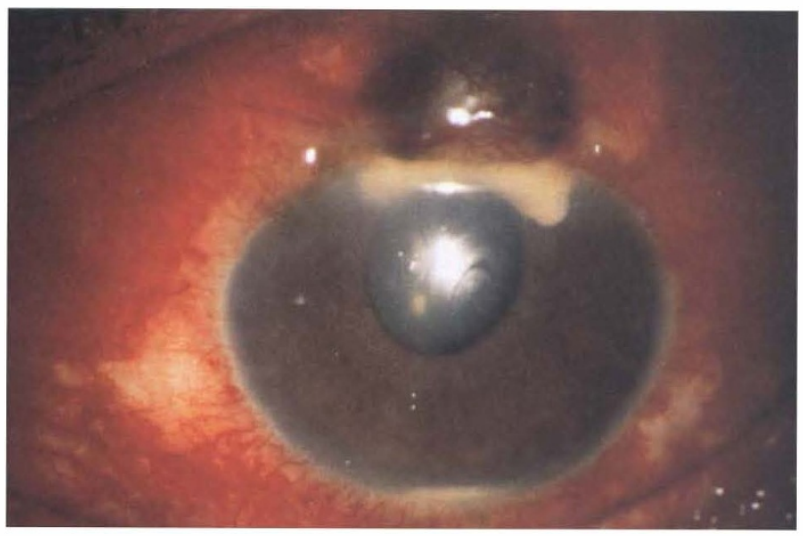

Fig. 7. Case 3. The left eye of a 54-year-old black man who had undergone trabeculectomy 3 months previously. Note the oval stapyhloma at the trabeculectomy site and the white infiltrate surrounding this lesion and reaching into the limbal cornea.

gentamicin $15 \mathrm{mg} / \mathrm{ml}$, cefuroxime $50 \mathrm{mg} / \mathrm{ml}$ and prednisolone $0.3 \%$. On this regime the inflammation began to subside and vision increased to $6 / 36$.

By 1 month after the patient had left the hospital, on 25 February 1994, her eye had become painful again and on examination a mild scleritis in the upper part of the globe was diagnosed. Therapy with oral flurbiprofen, in addition to the above medication, was started. Three weeks later this localised scleritis was more prominent; the intraocular inflammation, however, had almost resolved and vision had increased to $6 / 18$. Another 3 weeks later, on 6 April, the sclera became necrotic and a scleral biopsy was taken after the antibiotic treatment had been stopped for $48 \mathrm{~h}$. The histological examination revealed fungal elements and Aspergillus fumigatus was later isolated from the half of the scleral specimen that had been cultured. Therapy was changed to oral itraconazole $100 \mathrm{mg}$ twice per day and topical econazole 2 hourly. This medication was not effective in controlling the scleritis and over a period of 3 weeks a large necrotic area measuring $3 \times 10 \mathrm{~mm}$ developed. At this stage therapeutic surgery was planned.

Excision of a large area of necrotic sclera was carried out and the defect covered with two corneal patch grafts.

Post-operatively the inflammation began to subside and 2 months later, on 23 June, itraconazole was reduced to $100 \mathrm{mg}$ once a day. Visual acuity was then $6 / 18$. One month later all medications were discontinued. When the patient was discharged in November 1994, the eye was quiet with $6 / 9$ vision $(+1.5 /-2.0 \times 120)$.

\section{Case 3}

A 54-year-old black man who had undergone trabeculectomy in his left eye 3 months previously was referred to Moorfields Eye Hospital because of persistent inflammation of this eye. When he was first seen on 9 February 1990, vision was light perception with projection. Examination showed an oval staphyloma at the trabeculectomy site, measuring $5 \times 4 \mathrm{~mm}$, and a white infiltrate surrounding this lesion and reaching into the limbal cornea (Fig. 7). The overlying conjunctiva and episclera were intensely inflamed, and there were aqueous cells and a small hypopyon, but no vitritis. These findings and the fact that previous intensive and prolonged treatment with topical antibiotics and steroids had not cleared the inflammation prompted us to suspect fungal scleritis.

A surgical exploration of the trabeculectomy site with scleral and uveal biopsies was undertaken. The bacteriological studies were negative, but cultures on Sabouraud's medium showed fungal growth and subsequently Aspergillus sp. was identified. Histological examination revealed fungal elements in the scleral specimens that were consistent with Aspergillus. In addition to the intravitreal injection of $5 \mu \mathrm{g}$ of amphotericin B during the surgical exploration, a course of subconjunctival injections (750 $\mu$ g per injection) and topical amphotericin was instituted. On this regime there was increased intraocular inflammation with development of a dense cyclitic membrane across the anterior lens surface. One week after the first intervention diagnostic anterior chamber and vitreous taps were therefore taken and intravitreal injections of amikacin $0.4 \mathrm{mg}$ and vancomycin $1.0 \mathrm{mg}$ carried out. There was no growth of micro-organisms in these samples and steroids were started topically and orally. Fungal sensitivities showed minimal inhibitory concentrations of $0.25 \mathrm{mg} / 1$ to the imidazoles (itraconazole, econazole, clotrimazole), a concentration of $0.5 \mathrm{mg} / 1$ to amphotericin and resistance to flucytosine. These results are shown in Table 2 for comparison with those of the other two cases (the methodology of antifungal sensitivity testing has been described elsewhere ${ }^{11}$ ). Oral itraconazole (100 mg twice per day) and topical clotrimazole $1 \%$ were started. On this regime the inflammation began to subside.

On 19 March 1990, a cataract extraction via corneal section and an anterior vitrectomy were carried out. Biopsies of the anterior capsule and adherent iris were taken for histological and bacteriological investigation and both were positive for Aspergillus. The antifungal

Table 2. Activity of antifungal drugs against Aspergillus fumigatus strains isolated from scleritis cases

\begin{tabular}{lcccccccc}
\hline & \multicolumn{5}{c}{ Minimum inhibitory concentration (mg/l) for Aspergillus fumigatus isolates } \\
\cline { 2 - 7 } Case no. & Amphotericin B & Clotrimazole & Miconazole & Econazole & Ketoconazole & Intraconazole & Fluconazole & Nystatin \\
\hline 1 & 2.0 & $<0.12$ & 1.0 & $<0.12$ & 1.0 & $<0.03$ & $>64$ & Not done \\
2 & 0.5 & 0.5 & 1.0 & $<0.25$ & 2.0 & $<0.25$ & Not done & Not done \\
3 & 0.5 & $<0.25$ & 2.0 & 0.25 & 1.0 & $<0.25$ & Not done & 8.0 \\
\hline
\end{tabular}

${ }^{a}$ For methodology see Griffiths et al. ${ }^{11}$ 
sensitivities on the Aspergillus isolated at this time were identical to those from the previous culture. After cataract extraction a retrocorneal membrane adjacent to the corneal section developed over a 2 week period and the pupil became almost completely secluded with the development of a thick cyclitic membrane. Progression of fungus infection was assumed and an intravitreal injection of amphotericin $5 \mu \mathrm{g}$ together with amphotericin $750 \mu \mathrm{g}$ subconjunctivally over the staphyloma was carried out on 9 April. A course of 23 daily injections of subconjunctival amphotericin starting on 18 April followed. The oral steroids were tailed off during this period and the intraocular inflammation almost completely resolved. By 23 May the intraocular inflammation had completely resolved. To provide a view of the posterior segment, the cyclitic membrane was removed surgically on 23 May and iris, vitreous and scleral biopsies were taken. No Aspergillus was cultured from the multiple biopsies that were taken. Histological examination of the divided specimens, however, showed the presence of fungal hyphae in all iris and scleral specimens. Therapy with oral itraconazole $200 \mathrm{mg}$ twice a day was continued for another month together with topical steroids and the eye remained quiet with light perception afterwards.

\section{Discussion}

These case reports demonstrate the problems that may be encountered in the management of fungal scleritis. These include the difficulty of diagnosing mycotic infections, the choice of antifungal therapy, the difficulty of eliminating mycotic scleritis by medical therapy alone, and determining the technique and timing of surgical measures.

Scleritis is most frequently an aseptic, immunemediated inflammation that can occasionally be initiated by surgical trauma. ${ }^{1,12,13}$ Infectious scleritis after surgery should be suspected when there is no history of autoimmune disease and when the disease characteristics are atypical of immune-mediated scleral inflammation. Signs that were indicative of an infection in the reported cases include suture abscess, hypopyon, endophthalmitis and scleral necrosis without episcleral non-perfusion. Negative microbiology findings from swabs or scrapings are - as in fungal keratitis ${ }^{14}-a$ frequent finding and do not exclude an infection, since the organisms may be present only in the deep stroma. The diagnosis of Aspergillus infection was established in all three cases only after scleral biopsy. We recommend, therefore, as with bacterial keratitis, ${ }^{15}$ that in cases of progressive scleritis when infection is suspected, scleral tissue should be taken and divided for histopathological diagnosis and further microbiological investigations. The presence of mycotic elements on histological examination alone, without fungal growth in the cultured tissue, however, does not allow conclusions on their viability. Fungal elements may persist in the sclera after successful medical treatment, as shown by case 3 .
The management of patients with scleromycosis remains difficult despite the availability of new antifungal agents. There are no clear guidelines for the selection and administration of antifungal antibiotics since scleromycosis is extremely rare and in vitro sensitivity data are of only limited value. ${ }^{16}$ Topical and systemic antibiotic therapy is recommended for infectious scleritis. Until recently, amphotericin B was the drug of choice for systemic Aspergillus infection. ${ }^{16}$ More recently itraconazole has become an alternative to amphotericin B for this indication. ${ }^{17}$ Successful management solely by medical therapy was reported by Carlson et al. ${ }^{8}$ in one patient with Aspergillus scleritis following cataract surgery. These authors attributed the successful outcome to the use of oral itraconazole. Although itraconazole may have an enhanced efficacy and cause fewer problems with toxicity in comparison with amphotericin $B,{ }^{17}$ reliable control of mycotic scleritis by medical therapy alone is not the rule. In our cases 1 and 2 scleral inflammation was progressive and the formation of a necrotic area was observed while the patients were on oral itraconazole ( $200 \mathrm{mg} /$ day) and intensive topical antifungal medication.

Surgical methods are important means of controlling fungal scleritis. They should be considered in cases unresponsive to medical treatment. It has to be borne in mind, however, that massive inflammatory reactions may occur after initiation of medical therapy (as in case 3). These may represent an immunological response to fungal cell death rather than actual disease progression ('Herxheimer type' of reaction). ${ }^{18,19}$ Surgical interventions may consist of conjunctival resection with cryotherapy to the immediate surrounding sclera or lamellar or full-thickness procedures to excise the involved sclera with subsequent graft, or both, ${ }_{3}^{20,21}$ Surgical excision with subsequent grafting has the advantage over cryotherapy in that tissue for diagnosis is provided and the treated area is more clearly defined. The efficacy of the different surgical procedures in the management of fungal scleritis still needs to be clarified. This small case series demonstrates that, in selected cases, surgical intervention improves the outcome of this potentially devastating disorder.

The authors are grateful to Dr Yvonne Clayton who kindly provided the results of the antifungal sensitivity testing.

\section{References}

1. Watson PG. Diseases of the sclera and episclera. In: Duane TD, Jaeger EA. Clinical ophthalmology, vol 4. Philadelphia: JB Lippincott, 1995:1-45.

2. Köllner H. Schimmelpilzerkrankung der Sklera. Z Augenheilkd 1906;16:441-7.

3. Lincoff HA, McLean JM, Nano H. Scleral abscess. I. A complication of retinal detachment buckling procedures. Arch Ophthalmol 1965;74:641-8.

4. Milauskas AT, Duke JR. Mycotic scleral abscess: report of a case following a scleral buckling operation for retinal detachment. Am J Ophthalmol 1967;63:951-4.

5. Margo CE, Polack FM, Mood CI. Asperyillus panophthalmitis complicating treatment of pterygium. Cornea 1988;7:285-9. 
6. Moriarty AP, Crawford GJ, McAllister IL, Constable IJ. Fungal corneoscleritis complicating beta-irradiation-induced scleral necrosis following pterygium excision. Eye 1993;7:525-8.

7. Podedworny W, Suie T. Mycotic infection of the sclera. Am J Ophthalmol 1964;57:494

8. Carlson AN, Foulks GN, Perfect JR, Kim JH. Fungal scleritis after cataract surgery. Cornea 1991;11:151-4.

9. Chaillous J. Sporotrichose gommeuse disseminée, gomme intraoculaire, perforation de la sclerotique. Ann Ocul (Paris) 1912;148:321-8.

10. Stenson S, Brookner A, Rosenthal S. Bilateral endogenous necrotising scleritis due to Aspergillus oryzae. Ann Ophthalmol 1982;14:67-72.

11. Griffiths M, Clayton YM, Dart JKG. Antifungal sensitivity testing of keratitis isolates at Moorfields Eye Hospital 1975-1990: therapeutic implications. In: Bialasiewicz AA, editor. Infectious diseases of the eye: an update. Buren: Aeolus Press, 1994:190-4.

12. O'Doneghue E, Lightman S, Tuft S, Watson P. Surgically induced necrotising sclerokeratitis (SINS): precipitating factors and response to treatment. Br J Ophthalmol 1992;76:17-21.
13. Sainz de la Maza M, Foster CS. Necrotising scleritis after ocular surgery: a clinicopathologic study. Ophthalmology 1991;98:1720-62.

14. Polack FM, Kaufman HE, Newmark E. Keratomycosis: medical and surgical treatment. Arch Ophthalmol 1971;85:410-6.

15. Allan BDS, Dart JKG. Strategies for the management of microbial keratitis. Br J Ophthalmol 1995;79:777-86.

16. O'Day DM. Selection of appropriate antifungal therapy. Cornea 1987;6:238-45.

17. Mori T, Matsumara M, Ebe T, Takahashi M, Kohara T, Inagaki $\mathrm{M}$, et al. Clinical study of treatment of fungal infection with itraconazole. Jpn J Med Mycol 1991;32:279-90.

18. Koenig SB. Fungal keratitis. In: Tabbarra KF, Hyndiuk RA. Infection of the eye. Boston: Little, Brown, 1986:331-42.

19. Jones DB. Pathogenesis of bacterial and fungal keratitis. Trans Ophthalmol Soc UK 1978;98:367-71.

20. Reynolds MG, Alfonso E. Treatment of infectious scleritis and keratoscleritis. Am J Ophthalmol 1991;112:543-7.

21. Alfonso E. Surgical intervention in infectious keratoscleritis [letter]. Arch Ophthalmol 1994;112:1017-8. 